\title{
Acute Toxicity of Atrazine, Endosulfan Sulphate and Chlorpyrifos to Vibrio fischeri, Thamnocephalus platyurus and Daphnia magna, Relative to Their Concentrations in Surface Waters from the Alentejo Region of Portugal
}

\author{
P. Palma $\cdot$ V. L. Palma $\cdot$ R. M. Fernandes • \\ A. M. V. M. Soares · I. R. Barbosa
}

Received: 28 September 2007 / Accepted: 20 August 2008/Published online: 8 September 2008

(C) Springer Science+Business Media, LLC 2008

\begin{abstract}
Ecotoxicological effects of the herbicide atrazine and the insecticides endosulfan sulphate and chlorpyrifos were evaluated using a test battery comprising aquatic organisms from different trophic levels. According to the categories established in the EU legislation, atrazine can be considered non-harmful for the species tested, while the insecticides can be considered very toxic for the crustaceans. The results of acute toxicity tests showed that the sensitivity of organisms were as follows: Thamnocephalus platyurus $>$ Daphnia magna $>$ Vibrio fischeri. Chlorpyrifos may act as a toxic compound in the aquatic environment of Guadiana River, as it may be detected in water at levels that promote toxic effects.
\end{abstract}

Keywords Chlorpyrifos - Endosulfan sulphate ·

Atrazine $\cdot$ Aquatic ecotoxicity bioassays

The use of pesticides in agriculture may lead to contamination of surface and ground waters by drift, runoff, drainage and leaching (Cerejeira et al. 2003). Alentejo region (South of Portugal) is an important Portuguese agricultural area. The insecticides endosulfan sulphate and chlorpyrifos and

P. Palma $(\bowtie) \cdot$ V. L. Palma · R. M. Fernandes

Departamento de Ciências do Ambiente, Escola Superior

Agrária de Beja, Beja 7800-295, Portugal

e-mail: ppalma@esab.ipbeja.pt

P. Palma · I. R. Barbosa

Centro de Estudos Farmacêuticos, Faculdade de Farmácia,

Universidade de Coimbra, Rua do Norte, Coimbra 3000-295,

Portugal

A. M. V. M. Soares

CESAM \& Departamento de Biologia da Universidade de

Aveiro, Aveiro 3810-193, Portugal the herbicide atrazine are three of the pesticides most frequently used in Alentejo region crops. These compounds were chosen taking in account their concentration in the surface water of Alentejo region, mainly in Guadiana River, and their environmental significance. The herbicide atrazine may reach values above maximum admissible concentration (MAC) allowed by Portuguese Legislation for surface waters (Decreto-Lei n ${ }^{\circ} 236 / 98$ 1998). Despite that, atrazine did not pose a significant threat to the aquatic environment. However, Solomon et al. (1996) cautioned that, when atrazine is retained in small, standing-water reservoirs or has repeated inputs to a reservoir, damage can occur in the aquatic ecosystem. The organophosphorous (chlorpyrifos) and organochlorine (endosulfan sulphate) compounds were insecticides which promoted high acute and chronic toxicity to aquatic species (Wan et al. 2005; Zalizniak and Nugegoda 2006). Furthermore, some reports have indicated that endosulfan and atrazine may act as endocrine disruptors, and therefore can promote changes in aquatic population reproduction (Oehlmann and Schulte-Oehlmann 2003; McKinlay et al. 2008). Additionally, these pesticides are on the list of hazardous substances or priority pollutants reported by 2000/60/EC European Water Framework Directive. The pollutants on this list have been selected due to their environmental relevance and toxic effects to aquatic organisms.

The bioassays used were luminescent inhibition of Vibrio fischeri (bacterial species), Daphnia magna immobilization and Thamnocephalus platyurus mortality (crustacean species). The pesticides' acute toxicity was classified according to EU-Directive, which establishes toxicity categories for aquatic organisms, based on the values of effective concentration $\left(\mathrm{EC}_{50}\right)(\mathrm{EC} 1996)$.

The purposes of this study were to evaluate the acute toxicity of atrazine, endosulfan sulphate and chlorpyrifos using three species of non-target aquatic organisms, in 
order to assess which of the used organisms was the most sensitive species for the assessment of acute toxicity of these pesticides in Guadiana River ecosystem, and to determine if these pesticides may constitute a potential risk to this ecosystem.

\section{Materials and Methods}

Atrazine PESTANAL ${ }^{\circledR}(97.4 \%$ purity); endosulfan sulphate PESTANAL ${ }^{\circledR}(97.7 \%$ purity $)$ and chlorpyrifos PESTANAL $^{\circledR}(99.2 \%$ purity) were obtained from Riedelde-Häen Laborchemikalien GmbH. Stock solutions were prepared with dimethyl sulfoxide (DMSO) obtained from Merk $^{\circledR}$ (>99.0\% purity) as a carrier solvent (Hernando et al. 2007). Working stock solutions were prepared using MilliQ ${ }^{\circledR}$ water (resistivity $>18 \mathrm{M} \Omega \mathrm{cm}$ ) and made immediately prior to the test. The maximum amount of DMSO added, in all experiments, was lower than $0.01 \%(\mathrm{v} / \mathrm{v})$. Prior to the development of toxicity tests, the solution of DMSO in MilliQ ${ }^{\circledR}$ water was analysed to check the absence of toxic effects for the organisms used. The solution of DMSO prepared within the percentage of $0.01 \%(\mathrm{v} / \mathrm{v})$ did not show toxic effects. A DMSO negative control was included in all experiments. The experiments were performed with nominal concentrations of pesticides, which were not measured during the acute bioassays.

Luminotox ${ }^{\circledR}$ was used to evaluate the inhibition of the marine bacteria $V$. fischeri luminescence (NRRL B-11177), according to the protocol "DR LANGE luminescent bacteria test" following ISO 11348-2 (1998). The bacteria $V$. fischeri was supplied, as liquid-dried solution, by Dr. Lange $\mathrm{GmbH} \& \mathrm{Co} \mathrm{KG}$, Düsseldorf. The solution was stored at $-20^{\circ} \mathrm{C}$ and re-hydrated prior to the test. Tests were carried out on $50.0 \%, 25.0 \%, 12.5 \%, 6.25 \%$ and $3.125 \%$ of the stock pesticides nominal concentrations. Two replicates, per treatment, were used. The inhibition of the bacteria natural light emission was measured against a non-toxic control $(2 \% \mathrm{NaCl}$ solution). The samples were maintained at a temperature of $15^{\circ} \mathrm{C} \pm 0.5^{\circ} \mathrm{C}$. The $\mathrm{pH}$ of the pesticides samples was in the range of 6.5-7.0. For each sample, bioluminescence was measured before and after the desired incubation period (15 and $30 \mathrm{~min}$ ). The concentration of each pesticide that reduced $50 \%$ of the bacteria luminescence was determined.

D. magna were obtained from continuous cultures maintained in the lab at $20^{\circ} \mathrm{C} \pm 1^{\circ} \mathrm{C}$ with ASTM hard water (ASTM 1998) and a $16 \mathrm{~h}$ light:8 h dark photoperiod at a light intensity of 100-1,000 Lx. Animal density was 15 animals per $800 \mathrm{~mL}$. Daphnids were fed with algae (Pseudokirchneriella subcapitata) with a density of $3.0 \times 10^{5}$ cells $\mathrm{mL}^{-1}$ (an equivalent carbon content of $2.65 \mathrm{mg} \mathrm{C} \mathrm{mL}^{-1}$ ) three times per week. To evaluate the effects of the three pesticides on daphnids immobility/ mortality, tests were conducted in accordance with the standard protocol ISO 6341 (1996) of the International Organization for Standardisation. The nominal concentrations tested were the following: chlorpyrifos $\left(0.50 \times 10^{-3}\right.$, $0.65 \times 10^{-3}, 0.75 \times 10^{-3}, 0.80 \times 10^{-3}, 0.90 \times 10^{-3}$, $\left.1.00 \times 10^{-3} \mathrm{mg} \mathrm{L}^{-1}\right)$, endosulfan sulphate $(0.20,0.40$, $\left.0.60,0.75,0.80,0.90,1.00 \mathrm{mg} \mathrm{L}^{-1}\right)$ and atrazine $(30.0$, 35.0, 40.0, 60.0, 70.0, 80.0, $100 \mathrm{mg} \mathrm{L}^{-1}$ ). Four replicates, per treatment group, were used with five juveniles $(<24 \mathrm{~h})$ per glass jar, filled with $25 \mathrm{~mL}$ of test concentration. DMSO with a nominal concentration of $0.01 \%(\mathrm{v} / \mathrm{v})$ was used in the control group. Animals were not fed during tests. ASTM hard water had a total hardness of 160$180 \mathrm{mg} \mathrm{L}^{-1} \mathrm{CaCO}_{3}$, $\mathrm{pH}$ range of 7.5-8.0 and a conductivity of $580 \mu \mathrm{S} \mathrm{cm}^{-1}$. During the experiment the $\mathrm{pH}$, temperature, dissolved oxygen, conductivity and ammonium were monitored. After $48 \mathrm{~h}$ daphnids were observed for their mobility/death and the $\mathrm{EC}_{50}(\%)$ was determined.

To assess the effects of the three pesticides on the mortality of T. platyurus, tests were carried out in accordance to the standard operational procedure provided in THAMNOTOXKIT F ${ }^{\mathrm{TM}}$ (Persoone 1999). The concentrations tested were the following: chlorpyrifos $\left(0.40 \times 10^{-3}, 0.60 \times\right.$ $\left.10^{-3}, 0.80 \times 10^{-3}, 1.00 \times 10^{-3}, 1.20 \times 10^{-3} \mathrm{mg} \mathrm{L}^{-1}\right)$, endosulfan sulphate $(0.20,0.40,0.60,0.80, \quad 1.00$, $\left.1.20 \mathrm{mg} \mathrm{L}^{-1}\right)$ and atrazine (20.0, 40.0, 60.0, 80.0, $100 \mathrm{mg} \mathrm{L}^{-1}$ ). The nominal concentrations of pesticides were obtained in synthetic freshwater (water included in the test kit, also used as a control). Larvae of shrimp T. platyurus $(<24 \mathrm{~h})$, obtained by the hatching of cysts, were incubated in a 24-well plate test system, 10 crustaceans per well $(1.00 \mathrm{~mL}$ of test solution), three replicates per treatment, at $25^{\circ} \mathrm{C}$ for $24 \mathrm{~h}$ in the dark. The $\mathrm{pH}$ varied within 7.0-7.5. Animals were not fed during tests. The number of dead shrimp, for each treatment, was used as endpoint and the $\mathrm{EC}_{50}(\%)$ was calculated.

For all bioassays, a reference test with potassium dichromate $\left(\mathrm{K}_{2} \mathrm{Cr}_{2} \mathrm{O}_{7}\right)$ from Merck ${ }^{\circledR}$ was performed as a positive control. The sensitivity of the organisms was in accordance with the followed protocols. The control groups had a survival rate above $90 \%$.

Values of $\mathrm{EC}_{50}(\%)$ were calculated using the Probit analysis (MINITAB STATISTICAL Software ${ }^{\mathrm{TM}}$ 2000). For the Luminotox bioassays the $\mathrm{EC}_{50}(\%)$ values were determined using LUMISsoft 4 Software ${ }^{\mathrm{TM}}$.

\section{Results and Discussion}

The tested pesticides covered different classes of compounds with different mechanisms of action. Thus, the various toxicity assays could be assessed for their abilities 
to respond to a range of possible interactions between the toxic chemicals and the organisms. Table 1 showed that chlorpyrifos was the pesticide with the highest acute toxic effect to the bacteria $V$. fischeri $(30 \mathrm{~min}$ $\mathrm{EC}_{50}=2.84 \mathrm{mg} \mathrm{L}^{-1}$ ). The short-term effect promoted by this insecticide was above that reported by Somasundaram et al. (1990). Endosulfan sulphate promoted a slight toxic effect on $V$. fischeri $\left(30 \mathrm{~min} \mathrm{EC}_{50}=11.2 \mathrm{mg} \mathrm{L}^{-1}\right)$ as indicated in Table 1. Atrazine was the least toxic pesticide for this species $\left(30 \mathrm{~min} \mathrm{EC}_{50}=69.4 \mathrm{mg} \mathrm{L}^{-1}\right.$ ) (Table 1). According to the toxicity categories based on $\mathrm{EC}_{50}$ values, established in European legislation: "very toxic" to aquatic organisms $\left(\mathrm{EC}_{50} \leq 1 \mathrm{mg} \mathrm{L}^{-1}\right)$, "toxic" $\left(\mathrm{EC}_{50}\right.$ in the range of 1-10 mg L $\left.{ }^{-1}\right)$, and "harmful" $\left(\mathrm{EC}_{50}\right.$ in the range of 10 $100 \mathrm{mg} \mathrm{L}^{-1}$ ); chlorpyrifos can be classified as a "toxic" compound to this aquatic organism, while atrazine and endosulfan sulphate can be classified as "harmful". $V$. fischeri was the most tolerant organism to these three pesticides, in accordance with Strachan et al. (2001), who indicated that bacteria are not as sensitive to insecticides and herbicides as other aquatic organisms.

The toxic effects promoted in D. magna by the pesticides showed a similar trend with the other freshwater organisms tested. Chlorpyrifos promoted the highest toxic effect with a $48 \mathrm{~h} \mathrm{EC}_{50}=0.74 \times 10^{-3} \mathrm{mg} \mathrm{L}^{-1}$ (Table 1). Similar values of $48 \mathrm{~h} \mathrm{EC} \mathrm{EC}_{50}$, for this pesticide, were obtained by other authors (Tomlin 1994; Moore et al. 1998). Zalizniak and Nugegoda (2006) reported a $48 \mathrm{~h}$ $\mathrm{EC}_{50}=0.50 \times 10^{-3} \mathrm{mg} \mathrm{L}^{-1}$ for D. carinata, which suggests a similar sensitivity of both daphnid species. All these results showed the high sensitivity of the crustaceans to organophosphorus insecticides, presenting very low $\mathrm{EC}_{50}$ values for the most part of these compounds. This may be due to the mechanism of action of this class of chemicals, which inhibit cholinesterase enzymes (Fulton and Key 2001). Endosulfan sulphate also showed a high acute toxic effect to D. magna (48 $\mathrm{h} \mathrm{EC}_{50}=0.92 \mathrm{mg} \mathrm{L}^{-1}$ ). A similar result was obtained by Lemke (1980). Barry et al. (1995) reported a value of $48 \mathrm{~h} \mathrm{EC}_{50}=0.756 \mathrm{mg} \mathrm{L}^{-1}$ for $D$. carinata. These data indicate that $48 \mathrm{~h} \mathrm{EC}_{50}$ values for endosulfan sulphate for both daphnid species were in the same range. Nevertheless, Wan et al. (2005) obtained an acute toxic effect $\left(48 \mathrm{~h} \mathrm{EC}_{50}=2.12 \mathrm{mg} \mathrm{L}^{-1}\right)$ for $D$. magna, a value that is higher than that reported above. According to the toxicity categories, chlorpyrifos and endosulfan sulphate can be classified as "very toxic", for this aquatic species. Concerning atrazine, the results indicated that, in short exposures, this herbicide was not toxic

Table 1 Acute toxicity $\left(\mathrm{EC}_{50}\right)$ of selected pesticides to bacterial species (Vibrio fischeri) and freshwater species (Thamnocephalus platyurus; Daphnia magna). $\mathrm{EC}_{50}$ values are expressed as means (95\% confidence intervals)

\begin{tabular}{|c|c|c|c|}
\hline & \multicolumn{3}{|c|}{$\mathrm{EC}_{50}\left(\mathrm{mgL}^{-1}\right)$} \\
\hline & Vibrio fischeri & $\begin{array}{c}\text { Thamnocephalus } \\
\text { platyurus }\end{array}$ & Daphnia magna \\
\hline & $30 \min \mathrm{EC}_{50}$ & $24 \mathrm{~h} \mathrm{EC}_{50}$ & $48 \mathrm{~h} \mathrm{EC}_{50}$ \\
\hline Atrazine & $\begin{array}{c}69.4(68.8-70.0)^{\mathrm{a}} \\
(\mathrm{n}=2) \\
39.9(35.4-44.9)^{\mathrm{b}} \\
>39.9^{\mathrm{c}, *} \\
\end{array}$ & $\begin{array}{c}36.7(23.2-50.3)^{\mathrm{a}} \\
(\mathrm{n}=3)\end{array}$ & $\begin{array}{c}35.5(26.3-44.7)^{\mathrm{a}} \\
(\mathrm{n}=4)\end{array}$ \\
\hline $\begin{array}{c}\text { Endosulfan } \\
\text { sulphate }\end{array}$ & $\begin{array}{c}11.2(8.69-13.6)^{\mathrm{a}} \\
(\mathrm{n}=2)\end{array}$ & $\begin{array}{c}0.58(0.50-0.658)^{\mathrm{a}} \\
(\mathrm{n}=3)\end{array}$ & $\begin{array}{c}0.92(0.87-0.97)^{\mathrm{a}} \\
(\mathrm{n}=4) \\
2.12(1.45-3.99)^{\mathrm{e}} \\
0.74^{\mathrm{f}^{*}}\end{array}$ \\
\hline Chlorpyrifos & $\begin{array}{c}2.84(2.52-3.16)^{\mathrm{a}} \\
(\mathrm{n}=2) \\
46.0 \times 10^{-3} \mathrm{~d}^{*}\end{array}$ & $\begin{array}{c}0.53 \times 10^{-3} \\
\left(0.26 \times 10^{-3}-0.79 \times 10^{-3}\right)^{\mathrm{a}} \\
(\mathrm{n}=3)\end{array}$ & $\begin{array}{c}0.74 \times 10^{-3}\left(0.69 \times 10^{-3}-0.79 \times 10^{-3}\right)^{\mathrm{a}} \\
(\mathrm{n}=4) \\
0.60 \times 10^{-3} \mathrm{~g}^{*} \\
0.17 \times 10^{-3} \mathrm{~h}^{*}\end{array}$ \\
\hline
\end{tabular}

a Data reported in this work

b Tchounwoul et al. (2000)

c Hernando et al. (2007)

d Somasundaram et al. (1990)

e Wan et al. (2005)

${ }^{\text {f }}$ Lemke (1980)

g Moore et al. (1998)

h Tomlin (1994)

* $95 \%$ confidence intervals not reported 
for D. magna. Latt Phyu et al. (2004) measured a $48 \mathrm{~h}$ $\mathrm{EC}_{50}=24.6 \mathrm{mg} \mathrm{L}^{-1}$ for $D$. carinata, and reported that this species may be more sensitive than D. magna. However, for both biosensors, this herbicide can be considered as "harmful", according to the EU-Directive (EC 1996).

To our knowledge, this was the first study about the toxic effects of these three pesticides on $T$. platyurus. The pesticide which exhibited the greatest toxic effect in $T$. platyurus was chlorpyrifos $\left(24 \mathrm{~h} \mathrm{EC}_{50}=0.53 \times 10^{-3} \mathrm{mg} \mathrm{L}^{-1}\right)$, followed by endosulfan sulphate $\left(24 \mathrm{~h} \mathrm{EC}_{50}=0.58 \mathrm{mg} \mathrm{L}^{-1}\right)$ and atrazine $\left(24 \mathrm{~h} \mathrm{EC}_{50}=36.7 \mathrm{mg} \mathrm{L}^{-1}\right)$ (Table 1). The highly toxic effect induced by chlorpyrifos in the crustaceans was in line with the observations made by Barron and Woodburn (1995), who indicated acute toxicity to the majority of aquatic invertebrates, between $1.0 \times 10^{-2}$ and $1.0 \times 10^{-3} \mathrm{mg} \mathrm{L}^{-1}$. Both insecticides were classified as "very toxic" to this organism. Atrazine was classified as "harmful" for this aquatic species. The result was not surprising since its mechanism of action was to inhibit the photosynthetic electron transport and cell division in plants, and crustaceans do not have this biochemical pathway (Bowyer et al. 1991). T. platyurus showed a great sensitivity for the two classes of insecticides tested than D. magna. The high sensitivity of this crustacean was also reported by other authors for different classes of contaminants, such as pyrethroids (Sánchez-Fortún and Barahona 2005) and trace metals (nanosize and bulk particles of zinc, copper and titanium dioxide) (Heinlaan et al. 2008). However, for other compounds such as prednisone and dexamethasone, T. platyurus was less sensitive than D. magna (DellaGreca et al. 2004).

For evaluating the potential ecologic risk impact of these pesticides in aquatic ecosystems of the Alentejo Region, we examined the relationship between the acute toxic values obtained from the laboratory studies with the most sensitive species, and the quantified values of these pesticides in surface waters of Guadiana River. The values of these pesticides in surface waters were already reported by other authors (Cerejeira et al. 2003), and in a study by our group at Alqueva reservoir (integrated catchments of Guadiana) (Palma et al. 2007, submitted). This study was performed during 2006-2007 at nine sampling points in the Alqueva reservoir. Water samples were collected bimonthly (at $50 \mathrm{~cm}$ of depth, and stored in an amber bottle under cool conditions in the dark). The pesticides analyses were performed using gas chromatography according to DIN EN ISO 6468 (1996), with a limit of quantification of $0.01 \mu \mathrm{g} \mathrm{L}^{-1}$.

The results suggested that endosulfan sulphate is "very toxic" for invertebrates; however, its concentrations in surface water of Alentejo $\left(<0.01-1.80 \mu \mathrm{g} \mathrm{L}^{-1}\right)$ were approximately 2,000 times lower than the concentrations which promoted acute toxic effects. Therefore, it is not considered to be a hazardous compound for acute exposures in Alentejo waters. Atrazine is "toxic" to aquatic animal species when it reached values 600 times higher than those measured in surface water (0.01$5.50 \mu \mathrm{g} \mathrm{L}^{-1}$ ), so it can be considered a non-toxic compound without any acute risk impact to animal life. However, some plant species may be affected at concentrations near the upper end of this range (Solomon et al. 1996). Chlorpyrifos is the only one of the three pesticides analysed which may constitute a potential risk to aquatic animal species from acute exposures, since its concentrations in surface water of the Alentejo Region $(<0.01-$ $0.36 \mu \mathrm{g} \mathrm{L}^{-1}$ ) were in the same range as the $\mathrm{EC}_{50}$ values obtained in acute toxicity studies.

Results from this study confirmed that the toxicity test response, to the same pesticide, is strongly dependent on the sensitivity of the species used. The insecticides were more toxic than herbicides to the aquatic species tested. Furthermore, the freshwater crustacean species were more sensitive to all the pesticides than the bacteria species. Concerning the crustacean species, the results indicated that the most sensitive organism for the insecticides was $T$. platyurus. These results suggest that this species may be a good alternative for standard acute toxicity assays using Daphnia sp., and may justify its use in programs of aquatic risk assessment. This investigation provides evidence that the most toxic pesticide was chlorpyrifos, and that its toxicity for crustacean species was in line with the actual concentrations found in surface waters of the Alentejo Region. The results suggest that chlorpyrifos may have a real ecologic impact in this aquatic ecosystem, and may influence the density of some crustacean populations. This indicates a need for performing chronic studies with concentrations measured in surface waters of the Alentejo Region, and possibly with the surface waters themselves.

Acknowledgement The authors would like to thank "Programa Operacional Ciência e Inovação 2010" for financial support through the Project GG/GGP/ME621-0167/05, with partial funding from the FEDER.

\section{References}

ASTM (American Society for Testing and Materials) (1998) Standard practice for conducting toxicity tests with fishes, microinvertebrates and amphibians. In: Annual book of ASTM standards, E729-90. Philadelphia, p 271-296

Barron MG, Woodburn KB (1995) Ecotoxicology of chlorpyrifos. Rev Environ Contam Toxicol 144:5-16

Barry MJ, Logan DC, Ahokas JT, Holdway DA (1995) Effect of algal food concentration on toxicity of two agricultural pesticides to Daphnia carinata. Ecotoxicol Environ Saf 32:273-279. doi: 10.1006/eesa.1995.1114

Bowyer JR, Gamilleri P, Vermaas WFJ (1991) Photosystem II and interaction with herbicides. In: Baker NR, Percival MP (eds) Herbicides, vol 10. Elsevier, Amsterdam, p 27-85 
Cerejeira MJ, Viana P, Batista S, Pereira T, Silva E, Valério MJ, Silva A, Ferreira M, Silva-Fernandes AM (2003) Pesticides in Portugal surface and ground waters. Water Res 37:1055-1063. doi:10.1016/S0043-1354(01)00462-6

Decreto-Lei ${ }^{\circ}$ 236/98, de 1 Agosto (1998) Diário da República ${ }^{\circ}$ 176/98 - I Série A. Ministério do Ambiente. Lisboa

DellaGreca M, Fiorentino A, Isidori M, Lavorgna M, Previtera L, Rubino M, Temussi F (2004) Toxicity of prednisolone, dexamethasone and their photochemical derivates on aquatic organisms. Chemosphere 54:629-637. doi:10.1016/j.chemosphere. 2003.09.008

DIN EN ISO 6468 (1996) Water quality - determination of certain organochlorine insecticides, polychlorinated biphenyls and chlorobenzenes - gas-chromatographic method after liquid-liquid extraction; German version

EC (European Community) (1996) Technical guidance documents in support of directive 93/67/EEC on risk assessment of new notified substances and regulation (EC) $\mathrm{N}^{\circ} 1488 / 94$ on risk assessment of existing substances (parts I, II, III and IV). Off J Eur Commun

Fulton MH, Key PB (2001) Acetylcholinesterase inhibition in estuarine fish and invertebrates as an indicator of organophosphorus insecticide exposure and effects. Environ Toxicol Chem 20:3745. doi:10.1897/1551-5028(2001)020<0037:AIIEFA >2.0.CO;2

Heinlaan M, Ivask A, Blinova I, Dubourguier HC, Kahru A (2008) Toxicity of nanosized and bulk $\mathrm{ZnO}, \mathrm{CuO}$ and $\mathrm{TiO}_{2}$ to bacteria Vibrio fischeri and crustaceans Daphnia magna and Thamnocephalus platyurus. Chemosphere 71:1308-1316. doi: 10.1016/j.chemosphere.2007.11.047

Hernando MD, De Vettori S, Martínez Bueno MJ, Fernández-Alba AR (2007) Toxicity evaluation with Vibrio fischeri test of organic chemicals used in aquaculture. Chemosphere 68:724730. doi:10.1016/j.chemosphere.2006.12.097

ISO 6341 (International Organization for Standardisation) (1996) Water quality - determination of the inhibition of the mobility of Daphnia magna Straus (Cladocera, Crustacea) - acute toxicity test. Geneve, Switzerland

ISO 11348-2 (International Organization for Standardisation) (1998) International standard for water quality: determination of inhibitory effect of water samples on the light emission of Vibrio fisheri (luminescent bacteria test). Part 2: method using liquid-dried bacteria. Geneve, Switzerland

Latt Phyu Y, MStJ Warne, Lim RP (2004) Toxicity of atrazine and molinate to the cladoceran Daphnia carinata and the effect of river water and bottom sediment on their bioavailability. Arch Environ Contam Toxicol 46:308-315. doi:10.1007/s00244003-2313-5

Lemke AE (1980) Comprehensive report. Interlaboratory comparison of acute testing set. In: Ambient water quality criteria for endosulfan. EPA Environmental Research Laboratory, Duluth, Minnesota. US Protection Agency, Washington, DC
Mckinlay R, Plant JA, Bell JNB, Voulvoulis N (2008) Endocrine disrupting pesticides: implications for risk assessment. Environ Int 34:168-183. doi:10.1016/j.envint.2007.07.013

Moore MT, Huggett DB, Gillespie WB Jr, Rodgers Jr, Cooper CM (1998) Comparative toxicity of chlordane, chlorpyrifos and aldicarb to four aquatic testing organisms. Arch Environ Contam Toxicol 34:152-157. doi:10.1007/s002449900299

Oehlmann J, Schulte-Oehlmann U (2003) Endocrine disruption in invertebrates. Pure Appl Chem 75:2207-2218. doi:10.1351/pac 200375112207

Persoone G (1999) THAMNOTOXKIT $\mathrm{F}^{\mathrm{TM}}$ - Crustacean toxicity screening test for freshwater. Standard operational procedure. Belgium, p 3-21

Sánchez-Fortún S, Barahona MV (2005) Comparative study on the environmental risk induced by several pyrethroids in estuarine and freshwater invertebrate organisms. Chemosphere 59:553559. doi:10.1016/j.chemosphere.2004.12.023

Solomon KR, Baker DB, Richards RP, Dixon KR, Klaine SJ, LaPoint TW, Kendall RJ, Weisskopf CP, Giddings JM, Giesy JP, Hall LW Jr, Williams WM (1996) Ecological risk assessment of atrazine in North American surface waters. Environ Toxicol Chem 15:31-76. doi:10.1897/1551-5028(1996)015<0031: ERAOAI $>2.3 . \mathrm{CO} ; 2$

Somasundaram L, Coats JR, Racke KD, Stahr HM (1990) Application of the microtox system to assess the toxicity of pesticides and their hydrolysis metabolites. Bull Environ Contam Toxicol 44:254-259. doi:10.1007/BF01700144

Strachan G, Preston S, Maciel H, Porter AJR, Paton GI (2001) Use of Bacterial biosensors to interpret the toxicity and mixture toxicity of herbicides in freshwater. Water Res 35:3490-3495. doi: 10.1016/S0043-1354(01)00065-3

Tchounwoul PB, Wilson B, Ishaque A, Ransome R, Huang MJ, Leszczynski J (2000) Toxicity assessment of atrazine and related triazine compounds in the microtox assay, and computational modeling for their structure-activity relationship. Int J Mol Sci $1: 63-74$

Tomlin C (1994) The pesticides manual, 10th edn. British Crop Protection Council and the Royal Society of Chemistry, United Kingdom

Wan MT, Kuo J, Buday C, Schroeder G, Van Aggelen G, Pasternak J (2005) Toxicity of $\alpha-, \beta-,(\alpha+\beta)$-endosulfan and their formulated and degradation products to Daphnia magna, Hyalella azteca, Oncorhynchus mykiss, Oncorhynchus kisutch, and biological implications in streams. Environ Toxicol Chem 24:11461154. doi:10.1897/04-300R1.1

Zalizniak L, Nugegoda D (2006) Effet of sublethal concentrations of chlorpyrifos on three successive generations of Daphnia carinata. Ecotoxicol Environ Saf 64:207-214. doi:10.1016/ j.ecoenv.2005.03.015 